IRA-International Journal of Management \& Social Sciences

ISSN 2455-2267; Vol.04, Issue 02 (2016)

Pg. no. 477-482

Institute of Research Advances

http://research-advances.org/index.php/RAJMSS

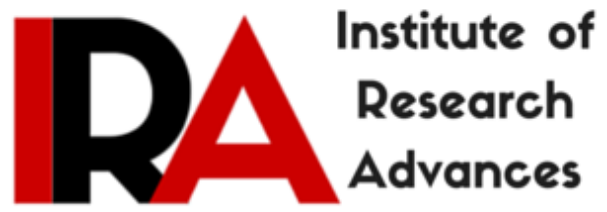

\title{
e-Governance Services: A special reference to Jana Seva Kendras of Odisha
}

\section{Dr Deepak Kumar Sahoo}

D. Lit, Research Scholar, Sambalpur University, Odisha

\& Head,

Dept of Business Administration,

Dhenkanal College (Autonomous), Dhenkanal, Odisha, India.

Type of Review: Peer Reviewed.

DOI: http://dx.doi.org/10.21013/jmss.v4.n2.p18

\section{How to cite this paper:}

Sahoo, D. (2016). e-Governance Services: A special reference to Jana Seva Kendras of Odisha. IRA-International Journal of Management \& Social Sciences (ISSN 2455-2267), 4(2), 477-482. doi:http://dx.doi.org/10.21013/jmss.v4.n2.p18

(C) Institute of Research Advances

\section{(cc) EY-NC}

This work is licensed under a Creative Commons Attribution-Non Commercial 4.0 International License subject to proper citation to the publication source of the work.

Disclaimer: The scholarly papers as reviewed and published by the Institute of Research Advances (IRA) are the views and opinions of their respective authors and are not the views or opinions of the IRA. The IRA disclaims of any harm or loss caused due to the published content to any party. 


\section{ABSTRACT}

In today's information technology environment, e-governance has become the essential part for the citizens to interact with the government. E-Governance is the application of information Technology to process of government functioning to bring about new SMART governance (Simple, Moral, Accountable, Responsive, and Transparent). Odisha state government has taken various innovative steps to promote eGovernance for IT implementation and delivery of services to the citizens online. While on one hand, the state government permitted private parties to establish and operate Jana Seva Kendra across the state, it is found, most of these centres who are managing lack adequate knowledge about the services provided by the district, state or central administration, and its application. The very purpose of opening and offering services for the ultimate benefit of the citizens often getting disrupted for former reasons, and there is no specific accountability or mechanism devised to control and regulates their functioning at district or state level. The general public can be immensely more benefitted with the variety, and trend of e-services provided by the different department and autonomous bodies in Odisha.

Keywords: G2C, B2C, G2B, B2B, NeGP, CSC, JSK, MMP.

Introduction: The term e-governance is of recent origin and there exist no standard definition since its conceptual understanding is still evolving. E-governance is beyond the scope of e-government. While egovernment is defined as a mere delivery of government services and information to public using electronic means, e-governance allows direct participation of people in government activities. As such egovernance brings a new concept of citizenship both in terms of needs and responsibilities.

Dr. A.P.J. Abdul Kalam, former President of India has visualized e-Governance in the Indian context to mean "A transparent smart e-Governance with seamless access, secure and authentic flow of information crossing the interdepartmental barrier and providing a fair and unbiased service to the citizen". Dr. Kalam, also quotes, "Delivery of service to citizens is considered a primary function of the government.

In a democratic nation over one billion people like India, e-governance should enable seamless access to information and seamless flow of information across the state and central government in the federal set up. No country has so far implemented and e-governance system for one billion people. It is a big challenge for us." E-governance promises a package of benefit to citizens by accelerating and automating government citizen interface, bring transparency in the functioning of the government and enabling democratization. E-governance develops new style of governance through by engaging citizen trust in the governance.

The government of India has initiated e-governance project in the country in late 1990s. The union government has approved that national e-governance plan (NeGP) comprising of 27 Mission Mode Projects (MMPs), 9 central (MMPs), 11 state (MMPs), and 7 integrated MMPs to give a boost to egovernance initiatives in India. Department of information Technology (DIT) and Department of Administrative reforms and public grievances (DAR \& PG) has formulated National e-governance plan (NeGP) with a vision to "Make all public service accessible to the common man in his locality, through common service delivery outlets and ensure efficiency, transparency and reliability of such services at affordable costs to realize the basic needs of the common man." The second Administrative Reform Commission (ARC) titled "promoting e-governance - The smart way forward" identified the needs for egovernance to bring government closer to its citizen (G2C).

Moreover, we assume electronic governance is the application of information Technology to process of government functioning to bring about new SMART governance. (Simple, Moral, Accountable, Responsive, Transparent).

e-Governance footage in Odisha: Odisha Government from time to time has taken appropriate steps and has put in place the administrative and bureaucratic machinery to have continuous focus on Citizen eServices. It may be pertinent to mention here that Government of Odisha had passed this landmark 
legislation, Odisha Right to Public Services Act in the year, 2012 to provide public services through a transparent and time bound process. Available data shows that 13 services of Commerce \& Transport, 3 services of Finance, 3 services of Fisheries \& Animal Resources, 2 services of Health \& Family Welfare, 8 services of Higher Education, 15 services of Home, 22 services of Housing \& Urban Development, 12 services of Revenue \& Disaster Management, 1 of Women \& Child Development, 1 of Rural Development, 2 services of Scheduled Tribe \& Scheduled Castes Development and 7 services of School $\&$ Mass Education Department have been notified under the Act. Out of this a total number of 37 services delivered by respective Departments have been made online.

Apart from this, a number of other IT initiatives have been applied by various Departments under e-Governance programme which are e-districts and e-Dharani project of Revenue Department, e-Municipality project of Housing \& Urban Development Department, CCTNS project of Home Department, e-Prenana project of Scheduled Tribe and Scheduled Castes Development Department, SARATHI and BAHAN project of Transport Department and VATIS project of Finance Department. The Government has a mandate to make additional 7 services of Home Department, 8 services of Higher Education Department, 16 services of Housing \& Urban Development Department, 6 services of Revenue \& Disaster Management Department and 7 services of School \& Mass Education Department online.

Major e-Services of Odisha: The broad objectives of these services are as under;

a) GRAMSAT: Odisha is the first state in India to introduce computerization with VSAT at the block level under the Gramsat pilot project. It is very essential to have a single official portal for the entire state of Orissa, to act as a single repository for the services offered by the State. Through this portal, the State has offered all informative, transactional, interactive and collaborative services to the people and business.

b) The Odisha State Portal: The Odisha State Portal modeled on the guidelines of India Portal, the State Portal (www.orissa.gov.in) provides a host of information and interaction services to citizens. The portal contains features that enable all the departments of the State Government to transact and communicate with definite technology.

c) OCAC: Odisha Computer Application Centre in short OCAC, the Technical Directorate of IT Department, is implementing the "Bhasha" project in association with Microsoft to provide Unicode Oriya support for developing ICT applications in Unicode Oriya.

d) e-Shishu Project: The Odisha Primary Education Programme Authority (OPEPA) has implemented eShishu Project, the first of its kind in India. The project has two components - Child Tracking System (CTS) and Intervention Monitoring \& Information System (IMIS). A comprehensive database of all the children below 14 years has been created which includes their socio-economic as well as demographic details under CTS, and all the 14 interventions under the Sarva Shiksha Aabhiyan are monitored online under IMIS.

e) e-dharani: The department of Revenue and Disaster Management has undertaken e-dhaRani, a comprehensive project of computerization of all Registration offices across the state. The two important features are benchmark valuation and document status of the registration of immovable properties.

f) e-Registration: Government of Odisha to increase the efficiency across the Administrative Structure has improved the quality of services to the citizens by registering the immovable properties across the state.

g) CT-MMP: Commercial Tax Department, Odisha to facilitate trade \& business in the State, improve regulatory oversight, deter tax evasion and encourage voluntary compliance. Various e-services launched by the department have become popular among the dealers and tax practitioners. The nature of interaction between the department and the dealers has undergone transformation due to the e-services. For eService visit: www.odishatax.gov.in 
h) iFMS: The Finance department, Odisha through Integrated Financial Management System undertakes Budget Distribution, Budget Estimation and Debt Management, Cyber Treasury, Treasury Monitoring and PL Deposits, GPF Queries, Teacher's PF, and Pension Preparation, RBI Interface, Bank Interface, AG Interface \& A/c Reconciliation, e-Payment, Reprint Challan, Accounts Correction, and Departmental Mail, Bill Query, Challan Query, Pension Payment, and Reports.

i) Odisha State Wide Area Network (OSWAN): The Odisha State Wide Area Network (OSWAN) serve as the backbone network for data, video and voice communications throughout the State which includes 1 State Head Quarter (SHQ), 30 District Head Quarters (DHQ), 284 Block Head Quarters (BHQ) and 61 Horizontal Offices.

j) e-Despatch: In the e-Despatch services used by both officials, and public the following government departments and bodies have participated in the network. The Departments are Agriculture, Commerce \& Transport, Co-operation, Electronics \& Information Technology, Energy, Excise, Food Supply and Consumer welfare, Finance, Fishery \& Animal Resources Development, Forest \& environment, General Administration, Health \& Family Welfare, Housing \& Urban Development, Higher Education, Home, Information \& Public Relations, Industries, Labour \& Employment State Insurance, Law, Micro Small \& Macro Industries, Panchyati Raj, Parliamentary Affairs, Pension Grievance \& Public Assurances, Planning \& Coordination, Public Enterprises, Revenue \& Disaster Management, Rural Development, Scholl \& Mass Education, Science \& technology, Skill Development \& Technical Education, Sports \& Youth Services, Steel \& Mines, Schedule Tribe \& Schedule Caste Development, Textile \& Handloom, Tourism Culture, Women \& Child Development, Works and Water Resources Department.

k) e-Municipality: e-Municipality Services have been implemented in 103 ULBs. The 103 urban local bodies (ULBs), categorized as Municipal Corporations (3), Municipalities (34) and Notified Area Councils (66). It provide citizen centric e-Services such as Birth and Death Certificate, Trade license, Property and Holding Tax, Water Connection Charges, Building Plan, Grievances, Certificate Verification.

l) e-Admission: Student Academic Management System (SAMS) provides a platform for college admission through e-Admission and several services to students in the colleges after admission also through e-Administration. The Higher Education department operates e-Admission and e-Administration through Students Admission Management System for enrolment into 10+2 and +3 (Degree) potential aspirants in all government and private educational institutions across the state and under the council of Higher Secondary Education,

m) e-District: Th portal provides these citizen centric e-Services such as Issuance of Residence Certificate, Issuance of Cast Certificate, Legal Heir Certificate, Issuance of SEBC Certificate, Issuance of Solvency Certificate, Issuance of Income Certificate, and Issuance of OBC Certificate.

n) e-Procurement: The e-Procurement System of Odisha enables the Tenderers to download the Tender Schedule free of cost and then submit the bids online through this portal.

o) Bhulekh: In the Bhulekh, the owner of the property or the buyer of the property or the citizens who have property for domestic or business purposes can get easily all the status or the information of their property. The states of Odisha have 51210 Villages in total. All the records of these villages are available on the Bhulekh website of the State.

p) e-PDS: Food, Supplies and Consumer Welfare Department has developed e-PDS for online registration for millers, societies, bulk consumers/institutions for PDS. It has also introduced mobile governance for monitoring rice delivery, transfer and paddy procurement.

q) e-FIR system under the Crime and Criminal Tracking Network and Systems (CCTNS) project: The Odisha Police has launched an e-FIR system under the Crime and Criminal Tracking Network and 
Systems (CCTNS) project, which has been sponsored by the Centre. This allows the citizens in the state to file their complaints online across 531 police stations in the state.

\section{Common Service Centres or Jana Seva Kendra's:}

In the line of Government of India Common Service Centre or Common Facilitation Centre, the State Government have set up e-Seva Kendras namely Jana Seva Kendra (JSK) in Urban areas to deliver Citizen Centric Service at their door step by providing Single Window facility. The state is mandate to open at least one centre in each 8558 number of Panchayat in 2006 to deliver Government to citizen (G2C), business to citizen (B2C), Government to business (G2B) and business to business (B2B) services. All these CSC's or Jana Seva Kendra's are being operated as ICT-enabled Kiosks having a PC along with basic support equipments like Printer, Scanner, UPS, with Wireless Connectivity.

The Scheme was implemented in June 2008 by OCAC through a Public-Private Partnership model. The Common Services Centres (CCs) were the strategic cornerstone of the Digital India Programme. They were the access points for delivery of various electronic services to villages, thereby contributing to a digitally and financially inclusive society. CSCs enable the three vision areas of the Digital India programme. CSCs are more than service delivery points in rural India. They were positioned as change agents, promoting rural entrepreneurship and building rural capacities and livelihoods. They were enablers of community participation and collective action for engendering social change through a bottom-up approach with key focus on the rural citizen. Services like Registration of Birth, Issue of Birth Certificate, Registration and issue of Death Certificates, Reservation and Cancellation of Kalyan Mandap, Payment of Water Bill and Payment of Holding Tax can be availed through these e-Seva Kendras.

The government taken a three pronged approach for effective implementation of National e-governance plan to enable anytime anywhere delivery of government services. Common Service Centres is a converged platform where the G2C (Government to Citizen) Services, B2C (Business to Citizen) Services, G2B (Government to Business) Services and B2B (Business to Business) Services can be delivered.

The Government of Odisha by entering an agreement with Srei Sahaj has established Common Services Centres or Jana Seva Kendra in 16 districts namely as Jharsuguda, Sambalpur, Boud, Sonepur, Bargarh, Bolangir, Nuapara, Nabaranbgpur, Kalahandi, Koraput, Malkangiri, Cuttack, Nayagarh, Jagatsinghpur, Puri and Khordha spanning in 3 zones. Similarly the Zoom Enterprises has been permitted to establish 3236 Jan Sewa Kendra in 10 District of Zone-1 Balasore, Bhadrak, Jajpur, Kendrapara, and Mayurbhanj and Zone-3 Keonjhar, Dhenkanal, Angul, Deogarh and Sundergarh, and M/s BASIX permitted to establish 1674 Jan Sewa Kendra in 4 Districts of Ganjam, Gajpati, Rayagada, and Phulbani.

Challenges: Our study finds several challenges before successful working of e-governance in Odisha. While on one hand, the state government permitted private parties to establish and operate Jana Seva Kendra across the state, it is found, most of these centres who are managing lack adequate knowledge about the services provided by the district, state or central administration, and its application. The operators who are establishing these Jana Seva Kendra are engaging non-technical persons with low knowledge about the background of e-services and it $\mathrm{s}$ benefits. They often lack in understanding the spirit of citizen centric services. Besides, the power and internet connectivity in the remote places are highly miserable, and thereby people lose their interest running after the centres, and go to urban places for such services. The very purpose of opening and offering services for the ultimate benefit of the citizens often getting disrupted for former reasons, and there is no specific accountability or mechanism devised to control and regulates their functioning at district or state level.

Conclusion: Govt. of India understands the demand of citizen's perspective and prepared the National eGovernance Plan (NeGP) with an aim to make all Government services accessible to the common man in his locality, through common service delivery outlets and ensure efficiency, transparency \& reliability of such services at affordable costs to realize the basic needs of the common man. The government of 
Odisha though has been making conscious effort to develop a well planned robust and futuristic IT architecture in the state which will bring about positive changes in all walks of life and society resulting in ease and convenience in transaction augmenting employment opportunities to the educated youth and ushering higher economic growth in a definite time frame, but establishment, and effective operation and monitoring of Jana Seva Kendra through which the services will reach is lacking. The general public can be immensely more benefitted with the variety, and trend of e-services provided by the different department and autonomous bodies in Odisha.

\section{References:}

1. Gupta, Kumar, Bhattacharya; Government on Line (Opportunities \& Challenges) Tata Mc Graw Hill, 2004,

2. Riley; Thomas, 2003, E-government vs E-governance: examining the differences in a changing Public Sector Climate, International tracking Survey Report '03, Commonwealth secretariat, 6.

3. Saxena; Towards excellence in E-Governance, Centre for Excellence in information management, CEXIM working Paper Series, management Development Institute, Gurgaon,2005,2

4. Kumar: (2005), An Institutional Framework for Good Governance in India workshop on Code of Good governance. Administrative staff college of India, Hyderabad. ASCI Journal of Management. 38-53. Retrieved from http:// journal.asci.org.in/ Vol. 34\% 282005\% 29 / 04. \% 20 G.N. \%20 Kumar. pdf on 27.09.14

5. Heeks R. (2001) Understanding .e-Governance for Development, Paper No. 11, Institute for Development Policy and Management University of Manchester, Precinct Center, Manchester, M13 9 GH, UK.

6. The 2006 e-readiness ranking. A white paper from the Economist Intelligence Unit The Economist Intelligence Unit, The Economist Group, London in co-operation with The IBM Institute for Business Value, 1.

7. Convergence And E-Governance (2001): Report of the Working Group On For The Tenth Five Year Plan (2002-2007), Planning Commission, Government of India,

8. http://en.wikipedia.org/wiki/E-Governance

9. http://india.gov.in/e-governance

10. http://deity.gov.in/content/e-governance

11. http://www.nceg.gov.in/

12. https://egovstandards.gov.in/

13. http://www.orissaonline.gov.in/site/default.aspx

14. http://edistrictorissa.gov.in/edistrict/index.php

15. http://www.oesl.in/

16. http://bhulekh.ori.nic.in

17. http://www.ocac.in/

18. www.oswan.gov.in/

19. https://www.ulbodisha.gov.in

20. http://ebloodbank.nrhmodisha.in/

21. http://orissa.gov.in/portal/default.asp

22. http://apps.nic.in

23. http://central.ortpsa.in 